DOI: 10.22363/2312-9182-2019-23-2-295-327

\title{
Translation Studies Today: Old Problems and New Challenges
}

\author{
Vadim V. Sdobnikov \\ Linguistic University of Nizhny Novgorod \\ 31-a, Minina Str., Nizhny Novgorod, 603155, Russia
}

\begin{abstract}
The article presents a review of the key trends in modern Translation Studies (TS) made after thorough analysis of the most fundamental works written in various fields of TS. The review proves that not only the range of problems within TS is now more diversified, which is related to many changes in the nature of translation activity, but Translation Studies are an interdisciplinary science now and uses data from neighboring disciplines. Specific "turns" have occurred in Translation Studies, and new paradigms of translation investigation have emerged. The most important phenomena in Translation Studies include "cultural turn" and the so called "anthropocentric turn" that has given birth to communicative-functional approach to translation. This approach implies "plunging" into the communicative situation of translation, and its analysis aimed at realizing the goal of translation by the translator/interpreter. It allows a more precise formulation of tasks solved by translators in both traditional types of translation (literary translation, religious translation, interpreting) and relatively new kinds of translation activity (audiovisual translation, localization). The article proves that translation proper is the main element of any activity performed by translators while any translation activity implies cultural adaptation of the text to the perception of the source text audience. The principal feature of Translation Studies is being practice-oriented, and their focus on the study of objective laws of translation activity. It enables translation scholars to understand peculiarities of various types of translation and to realize the essence of translation as a human activity.
\end{abstract}

Keywords: Translation Studies, cultural turn, communicative-functional approach, audiovisual translation, localization

\section{For citation:}

Sdobnikov, Vadim (2019). Translation Studies Today: Old Problems and New Challenges. Russian Journal of Linguistics, 23 (2), 295-327. doi: 10.22363/2312-9182-2019-23-2-295-327.

\section{Переводоведение сегодня: вечные проблемы и новые вызовы}

\author{
В.В. Сдобников \\ Нижегородский государственный лингвистический университет \\ им. Н.А. Добролюбова \\ ул. Минина, 31-А, Нижний Новгород, 603155, Россия
}

\begin{abstract}
Аннотация
В данной статье представлен обзор основных тенденций в современном переводоведении, предпринятый на основе изучения наиболее значимых работ, созданных в разных областях науки о переводе. Обзор свидетельствует о том, что не только проблематика переводоведения стала более разнообраз-
\end{abstract}


ной, что связано с определенными изменениями в характере самой переводческой деятельности, но и само переводоведение приобрело междисциплинарный характер, вовлекло данные смежных дисциплин. В рамках переводоведения произошли определенные «повороты» и возникли новые парадигмы исследования перевода. К числу наиболее важных явлений в области переводоведения относятся «культурный поворот», а также «поворот», который можно назвать антропоцентрическим, послуживший основанием для развития коммуникативно-функционального подхода к осуществлению и изучению перевода. Он предполагает «погружение» переводчика в коммуникативную ситуацию, в которой осуществляется перевод, ее анализ с целью уяснения цели перевода. Данный подход позволяет более точно сформулировать задачи, решаемые переводчиками в рамках осуществления как традиционных видов перевода (художественный перевод, религиозный перевод, устный перевод), так и относительно новых видов переводческой деятельности (аудиовизуальный перевод, локализация). В статье обосновывается утверждение, что собственно перевод является главным элементом любой деятельности, осуществляемой переводчиком, и всякая переводческая деятельность предполагает культурную адаптацию текста к восприятию получателей перевода. Основная особенность переводоведения сегодня - его ориентированность на практику, на изучение закономерностей переводческой деятельности, что дает возможность постижения как особенностей различных видов перевода, так и сути перевода как вида человеческой деятельности.

Ключевые слова: переводоведение, культурный поворот, коммуникативно-функциональный подход, аудиовизуальный перевод, локализация

\section{Для цитирования:}

Сдобников В.В. Переводоведение сегодня: вечные проблемы и новые вызовы // Вестник Российского университета дружбы народов. Серия: Лингвистика $=$ Russian Journal of Linguistics. 2019. T. 23. No 2. C. 295-327. doi: 10.22363/2312-9182-2019-23-2-295-327.

\section{INTRODUCTION}

It is well known that translation studies acquired the status of a science in the second half of the $20^{\text {th }}$ century. It was quite a natural phenomenon preconditioned, first and foremost, by the need to interpret the objectivity and peculiarities of translation activity that had changed dramatically and expanded its boundaries. It seems to be quite natural that the new science was created not from scratch but used a number of concepts that had appeared in previous epochs. Ideas that had emerged in translators' minds in various countries and in various times paved the way to formulation and formalization of isolated views on translation in the form of an entity that eventually became a science. It is obvious that in previous periods the translators' thinking was concerned with only two types of translation activity that had been dominant over centuries, specifically, religious translation, i.e. translation of sacred texts, and literary translation. It is not accidental that it was the literary approach to translation that became the first and the most dominant one in translation studies, if the term "translation studies" is applicable to translation investigations in the pre-scientific period, so to speak. It was only in 1930s when researchers paid their attention to problems of specialized, non-literary translation, which was preconditioned by the extended international cooperation in the scientific and technical, military and diplomatic fields as well as by the need to train translators for the fields (Sdobnikov, Petrova 2006: 54-55). Linguists' interest in the comparative synchronic study of languages contributed much to the emergence of the linguistic approach to translation. Edwin Gentzler argues that "....a more systematic approach to translation was needed, and the discipline with the theoretical and language tools necessary to address the problem was first provided by linguistics" (Gentzler 1990: 67). 
Translation scholars of the time were mostly interested in types of the correlation between the languages that clashed in the process of translation and that influenced the translation process and its results. It was a kind of a "turn" from literary studies to linguistics resulting in a confrontation of and even hostilities between the two approaches, at least in Russia. The fight ended with the general recognition of the fact that even in literary translation linguistic factors play significant role at the both stages of the translation process, i.e. in the source text interpretation and the target text production (Larin 1962: 3). Thus, a reconciliation took place. But it was just the initial period of the development of the science of translating. Further I shall consider the main events in the history of translation studies and in the history of translation activity to which TS is linked and which let the science acquire its present form and status.

\section{TURNS IN TRANSLATION STUDIES}

\subsection{Cultural Turn}

Further development of Translation Studies was marked by some important shifts, as Western scholars termed them (Snell-Hornby 2006). I shall mention only the most significant events that have predetermined the present state of Translation Studies, referring to more extensive literature on the matter (Gentzler 1990; Prunč 2007; Прунч 2015) for those who need more detailed information about the TS development

Proceeding from the premise that any turn implies a change of direction, of a motion vector, I, first, shall note the approach that served as the start point of the further development of the science of translating. Based on the logic of how things unfold, it is quite natural to presume that it was the linguistic approach that appeared at the early state of the TS formation. Briefly speaking, the main task set according to this approach was seen as finding conditions of establishing equivalence of the two texts as well as factors that contribute to or prevent it. It is not accidental that what is called linguistic approach in Russian Translation Studies is termed equivalence-oriented approach or equivalence paradigm (Gambier 2016a) in the West. With time, the limitations of this approach got to be realized. Ives Gambier argues that this approach "does not allow one to consider, describe, and explain the translation decisions and the translated output. The distinction between what is manifest (literal, direct, surface level) and what is latent (implicit, connotative, underlying) misreads the process of translation and relegates the translator's act of interpreting the content to a task of relative obscurity" (Gambier 2016b: 889).

TS could not stay in the grip of the linguistic approach for a long time, especially when the nature of translation activity itself was forcing scholars to consider the issues related to the impact of cultural factors on translation. Translation Studies dramatically changed when it was realized that in translation not only languages clash but cultures do as well. Alexander Shveizer claimed that in translation the clash of cultures happens both at the communicative level and at the level of the text (Shveizer 1988: 52). Talking about cultures scholars, at the same time, meant representatives of different cultures, i.e. people for whom translation is a means to ensure communication. Thus, the term "cross-cultural communication" became wide-spread. And in theoretical studies of 
translation a place that had used to be vacant got opened up - a place for humans. It was both a cultural and anthropocentric turn in translation.

Extensive literature was devoted to the influence of culture on translation and the influence of translation on culture since 1980s (Bassnett, Lefevere 1998; Bassnett 2005; Cranmer 2015; Gentzler 2001; Hatim, Mason 2005; Katan 2009; Koskinen 2015; Nida $1973 ; 1993 ; 1996$; Toury 1984). It is obvious that the notion of cultural turn is a very complex and multidimensional one, and in this respect is similar to the notion of culture itself. It could not but influenced the character of the science of translating which started to investigate various aspects of cultural manifestations and differences between cultures apparent in various types of translation. The fact is confirmed by the topics of the articles of the present issue of the journal discussing mechanisms of cross-cultural communication that must be taken into account by translators and studied by translation scholars.

\subsection{Functionalist Approach to Translation: a Way to Future}

I believe that functionalist approach to translation (I call it communicative-functional approach) traces it origin to the works by Eugine Nida (Nida 1964; Nida, Taber 1969), authors of scopos theory Katharina Reiss and Hans Vermeer (Reiß, Vermeer 1984; 2013) and scholars of Leipzig school of translation (Jäger 1975; Kade 1981; Neubert 1973). However, if we take into account that the communicative-functional approach is based on the assumption that the translator's task is to perceive the global meaning of the ST and to reproduce it in the target text, we can say that the list of precursors of this approach includes Cicero, St. Jerome and even Peter the Great (see, e.g., Fedorov 1983: 41). Among Russian translation scholars we should mention Zinaida Lvovskaya (Lvovskaya 2008) who paid special attention to rendering meaning for a definite audience (Sdobnikov 2017).

Nowadays the communicative-functional approach dictates that any translation event must be viewed in the contest of a certain communicative situation with due account of the translation goal, needs and expectations of real or probable TT recipients (consumers), and the way the TT will be used by the text consumers in their substantive activity. In some cases it is important to take into account the communicative intention of the ST sender and the communicative effect produced by the ST on its recipients. I say "in some cases" because the equality of communicative effects produced by the ST and the TT is not always necessary and often is utterly impossible. For example, a translation of a speech initially addressed to the ST audience can hardly have the same effect on another audience. This statement contradicts the traditional views according to which translation is a process with the objective to reproduce the communicative effect of the source text (Shveizer 1988: 75).

Since the analysis of the communicative situation in which translation is made is an indispensible condition of realizing translation brief by the translator (Nord 2005: 910 ), it is required to classify such communicative situations. The classification I have developed includes two types of communicative situations: those in which translation is planned initially, i.e. at the time the ST is created, and those in which translation is not initially planned. Each of these types is further subdivided on the basis of different 
criteria: in the first case it is the form of interaction of interlocutors (a presentation, a round table, an interview, a guided tour, etc.), in the second case it is the personality of the translation commissioner (Sdobnikov 2011; Sdobnikov 2015). I state that the parameters of a communicative situation determine the translation goal and are instrumental in choosing the translation strategy that conforms to the situation; translation strategy is defined as a general program of performing translation activity with due account of the parameters of the communicative situation (Sdobnikov 2011: 1450).

Thus, the communicative-functional approach implies plunging - both in theory and practice - into a certain communicative situation, realizing the parameters of this situation and the tasks that must be solved by the translator. This approach is of special importance for professional training of translators and interpreters because it allows to get rid of the false vision of translation as a transformation of one text into another, as a philological game, and to implant the idea in would-be translators' minds that translation is an activity aimed at satisfying the needs of people by producing a text in the target language on the basis of the source text. This conviction will be typical of future generations of translators if the communicative-functional approach becomes their ruling ideology.

\subsection{Eternal Problems of Translation Studies}

Translation Studies continue to pay special attention to problems discussion of which began many centuries ago. The list of these problems includes issues of literary translation and religious translation covered, by the way, in some articles published in this issue. It might seem that everything that can be said about these problems has already been said, and there is nothing to add. But it is not the case. The thing is that the development of Translation Studies must be viewed as spiral movement: at each new cycle translation scholars embrace new aspects of eternal problems, their approaches to solving translation problems change, they approach the problems with a fresh perspective. Undoubtedly, it is the communicative-functional approach that is the basic and most promising approach to translation, which seems to be a very innovative fact, especially in relation to translating sacred texts. In particular, this approach is congruent to the task of ensuring a specific communicative effect on the recipients of a translated version of the Bible and taking into account the mission that must be performed by translations of the Holy Scripture in the target culture in a certain epoch (see, for example, the article by G. Khukhuni, I. Valuitseva and A. Osipova). I am happy with the fact that the communicative-functional approach is used as the theoretical framework that allows to make investigation of eternal (and new) problems of Translation Studies closer to the reality of the translation activity performed in the interests of specific ST recipients in specific situations.

\subsection{Translation Studies Today: New Trends}

The brief overview of Translation Studies today will be completed with consideration of new fields, trends and topics that became topical over the last two or three decades. Certainly, it is hard to list all specific issues that are of great interest to translation scholars within the limited space of this review. The most important thing is that 
Translation Studies have already proved that it is practice-oriented; all innovations in Translation Theory are predetermined by changes in the translation activity's character. A sketchily overview of the most significant changes and their role in diversifying Translation Studies agenda is given below.

\subsubsection{Development of Interpretation Theory}

It seems that the development of Interpretation Theory is not a recent achievement. But we should take into consideration that the initial stage of the development of science of translating only left us with some landmark books that laid the foundations of Interpretation Theory and mapped out the ways of investigating interpretation as an activity (Minyar-Beloruchev 1969; 1980; Chernov 1987; Shiryaev 1979). The research used the purely linguistic (or text-oriented) approach that was dominant that time. Now translation scholars focus not only on describing the mechanisms of consecutive and simultaneous interpreting but on investigating psycholinguistic and neurophysiological processes that underpin the mechanisms (Moser-Mercer 1978; Moser-Mercer et al. 1998). The most innovative, even striking trend in simultaneous interpreting is the so called "solo" simultaneous made individually, i.e. without a partner. Some empirical research is carried out in field, though no fundamental works on the issue have been written so far.

\subsubsection{Investigation of Audiovisual Translation}

The wider use of audiovisual translation (AVT), i.e. translation of movies, cartoons, video presentations, computer games, applications to smartphones, etc., could not but attracted attention of translation scholars (Gorshkova 2006; 2017; Matasov 2009; Malyonova 2017; Chaume 2016; Díaz Cintas 2009; Gambier 2008). Many of them treat AVT as an independent activity distinct from interpreting and translation (Kozulyaev 2013). This field embraces two spheres of research. First, it is investigation of specific peculiarities of AVT as a translation activity and its technologies, such as overvoice, dubbing, subtitling (Gottlieb 2009; Pettit 2009). Second, it is investigation of particular problems faced by translators in the AVT process, mostly, in film translation (translation of movie titles, puns, metaphors, etc.). It is encouraging that scholars decline the textoriented approach in investigating the specific translation problems (Malyonova 2017: $40-41)$ and use the communicative-functional approach, or polydisciplinary approach, to be more exact (Malyonova 2017). The fact is confirmed by the articles of Olga Leontovich, N. Shchurik and V. Gorshkova published in the present issue. The vision of AVT as an individual translation activity is based on taking into account its polysemiotic character (Kozulyaev 2013; Malyonova 2017; Díaz Cintas 2009), which implies that AVT must be studied both as a type of intersemiotic translation and as a method of producing a specific communicative effect on a specific audience.

\subsubsection{Translation vs Localization?}

Obvious "technologizing" of the translation process, the usage of translation in creating such products as computer games, mobile applications, interfaces of websites, etc., have resulted in the differentiation of translation proper and the so called localization in practical activities and in emergence of new paradigms in translation theory (Gam- 
bier 2016a; 2016b). For example, Anthony Pym argues that IT are not just additional tools but systems that “.... are altering the very nature of the translator's cognitive activity, social relations, and professional standing" (Pym 2011). Localization must satisfy the need to modify the functions and features of the applications in such a way that they would fulfill the requirements and demands of local consumers (Gambier 2016b: 890). It is defined as "the process of modifying products or services to account for differences in distinct markets" (LISA 2003: 13). Localization of a product for another cultural environment implies addressing three types of issues - linguistic, cultural and technical. Adaptation of accounting software to comply with local generally accepted accounting principles in the target culture is just one example of cultural issues (Ibid.). Redesign and re-engineering of software to support local languages and content is a technical issue. Thus, localization is closely related to translation but is more extensive, and implies some technical operations necessary to adapt the text to the needs of consumers in another culture.

I do not think that opposing localization to translation proper is fully justified. Unfortunately, it is a trend both in the translation theory and translation business. Some managers of translation agencies view translation as transformation of one text into another, replacement of signs (words) of one language by signs of another. At the same time, localization is presented as a process in which significant cultural (pragmatic) adaptation of the text to the reality of the target culture is made (Fridge). It is stated that no cultural adaptation is performed in the process of translation proper (Ibid.). Certainly, it is not the case. We know pretty well that any translation implies cultural adaptation (Komissarov 1990: 211-215), especially translation of publicistic, literary, advertising materials and even specialized texts. Therefore, localization is distinct from translation proper in the use of certain technical tools needed to create a product in conformity with the requirements of a local market. Moreover, I can conclude that Translation Studies are expected to define precisely the place and role of translation in the localization process and the place of localization in the general structure of translation activities.

\section{THE ARTICLES OF THIS ISSUE}

In her article Christiane Nord considers peculiar features of book titles and possible paradigms of their translation from one language to another. At the first glance, the issues seem to be purely technical, and do not require any theoretical insight into the matter. Yet, the fact that the author discusses these specific issues from the functionalist perspective proves that any translation problem can be viewed in a broader context, on the basis of some theoretical approach. It is well-known that Christiane Nord is a faithful disciple of Hans Vermeer and Katharina Reiss, founders of the scopos theory (Reiss, Vermeer 1984), and has contributed a lot to the development of the functionalist approach to translation (Nord, 1991). One of the most outstanding premises of the scopos theory is that translation activity should be always audience-oriented and performed in accordance with the translation brief. This approach is evident in the consideration of all aspects of the issue. E.g., talking about such standards of textuality as cohesion, coherence, intentionality, acceptability, informativity, situationality, and intertextuality, 
Nord argues that recipients need an experience of titles in order to be able to recognize the title as a signal for an offer of communication about a text, and to make sense of the information given in the title. Intentionality means that authors or senders who produce a text usually have some communicative intentions in mind. Acceptability implies that recipients must be willing to make sense of a text. Informativity of the title should therefore spark the reader's interest in the co-text. We may conclude, therefore, that behind or, to be more exact, within any act of translation we see figures of the ST sender and the TT recipients. The result of the translation act is dependent on the Sender's communicative intention, the needs of the TT recipients, thus, on the translation goal. Nord concludes that since a title is a text "about" another text, it can be regarded as "metatext", and, at the same time, it has a specific relationship with its object text, without which it cannot fulfil its function as a title. Being communication tools, titles perform the following functions specified in the article: distinctive, referential, expressive, phatic, appellative functions. The mere composition of the article is a hint at the need to render all these communicative functions in translation. In doing this, a translator is expected to grasp the situationality of a title, which is determined by such extratextual factors as medium, time, place or motive of production and reception. For a title, audience and function orientation is extremely important because a translated title must be appropriate to achieve the desired functions in the title corpus of the target culture and fidelity or faithfulness with regard to the source-text title. Thus, the author comes to the conclusion that the methodology used for the analysis of title translation can serve as a paradigm for a functional translation of other texts or text types.

The article of Ives Gambier presents an overview of the changes in attitudes toward translation as activity and profession as well as toward its roles and the need in it in the past and present. The author argues that translation and interpreting are but one possible solution among many implemented in multilingual communications (people can learn foreign languages and, thus, do without translation; languages can co-exist with speakers practicing bilingualism; a lingua franca can be used). Further, the author considers denial of translation as a need, an effort and profession. It is noteworthy that those who deny translation as effort stick to the naïve and simplified opinion according to which translation comes down to replacement of words of a language with words of another language, and this replacement can be done by any person lacking special training. Those who deny translation as profession view the translator as a hardworking hermit or an impostor, instead of a mediator or an expert. Gambier also claims that denial has long been present with regard to translation as an autonomous discipline; as a result, many translator training programs are still reluctant to give Translation Studies a place they deserve.

The author considers thoroughly many changes in the activity of translation caused by the use of information technologies; he argues that due to the wide use of various technical tools translation users adopt an illusory view of translation as an instantaneous activity performed without any effort. It can also be noted that cloud technologies and real-time data exchange facilitate the activity of translators and managers and help cut costs. The author notes that in real life there is a differentiation between professional translation in the process of which translators can build teams and exchange data using 
CAT systems, and amateur translation (translation by fans, volunteer networked translation and the like). The topic relates to the author's considerations of the peculiarities of the global, regional and local translation markets.

Gambier notes a multiplication of labels created nowadays for "translation". Alongside with the term "translation" the translation discourse is abundant with such new terms as localization, adaptation, multilingual documentation, editing, trans-editing, multilingual technical writing, language mediation, versioning, revision, co-writing. Not infrequently translation is opposed to these kinds of activities and sometimes is denied as a need. The opposition is based upon incorrect vision of translation as replacement of words of one languages with words of another language, though the notion of translation as a creative activity has been returning to Translation Studies recently. The author notes that the diversity of labels for translation ruins the stability of Translation Studies since the object of investigation becomes vague and defused.

Ives Gambier concludes that two paradigms are evolving in Translation Studies: on the one hand, the more conventional paradigm of equivalence has evolved into the one more oriented toward the audience, i.e. the paradigm of the 'cultural turn'; on the other hand, the paradigm oriented toward the digital culture has emerged. A question arises: can Translation Studies become a trans-discipline or shall we witness emergence of many disciplines (Adaptations Studies, Intercultural Studies, Transfer Studies, Knowledge Management, Internet Studies, etc.)? The author claims that instead of absorbing neighboring disciplines Translation Studies must recognize the complexity of communications and behaviours.

Marta Kaźmierczak addresses the problem of rendering intertextual markers in translation of poetry. Though the problem is not new, and has been widely discussed in the Translation Studies literature, the article published in this issue must be treated as innovative for, first, the author's approach toward the solution of many problems faced in rendition of intertextuality and, second, for the observations made by the author. The peculiar character of the approach lies in the consideration of the problems arising during translation among languages and cultures the distance between which is noticeably large (in our case it is English and Polish cultures). Thus, the article explores sourceculture references in the literatures less known internationally which, as Kaźmierczak puts it, is a sphere of especial cultural resistance to translation. The author focuses on the importance of the level of explicitness of intertextual links for the task of a translator and on the degree of recognisability of intertextual markers.

Undoubtedly, the author's approach can be termed a functionalist one: it is evident from the text that since intertextual markers perform certain functions in a source text it is necessary to render them in a way that allows to trigger a certain reaction on the part of the target text recipient. Kaźmierczak analyses the crucial factors that can hinder the TT recipient's perception of intertextuality, with low recognisability of the source-culture referent being the most important one. The author argues that this is due to the "imbalance of power" between the cultures from which and into which translators are working. Among interesting observations concerning rendition of intertextuality I would mention the following ones. First, the author insists that even an illegible (not readily decipherable) marker would be a signal of intertextuality for the TT recipients. 
For example, a transferred foreign name would have been a stronger (a more explicit) intertextual marker than a naturalised, semantically transparent one while footnotes is a means of explicitation of limited applicability and not suitable for poetry. The most important conclusion made by the author is as follows: it is the projection of the reader, of his/her cultural competence and needs that shapes the translation strategy, even more so with respect to intertextual elements. In other words, a successful translation of intertexts is possible if the translator construes his role as levelling the differences in erudition between the primary and the secondary recipients.

The paper of Natalia Yarkina, Liudmila Yarkina and Ivan Pougachev is remarkable for its attempt to deal with situations where the ideologies of the ST audience and the TT audience clash. Ideology is defined in the paper as a set of beliefs and values shared by a social group. It affects all the parties involved in the translation process and influences the work of the translator in various ways. The authors claim that the goal of the intergroup mediation approach to translation of ideology is to find an adequate way to convey the author's message under the conditions of an ideological conflict. The paper attempts to answer the questions regarding the conditions under which ideology-related interventions may be desirable and deemed acceptable and what factors influence the translator's decisions, in particular, ideological shifts in translation. By "ideology shift" the authors mean a situation where an ideology-motivated element or feature of the source text is transformed in the target text in such a way that it does not express the source ideology any more, or, vice versa, an ideological element or feature is introduced in the target text, thus adding an ideology that was not present in the source text. Therefore, the paper discusses problems which relate to situations when ST expresses an ideology that contradicts the ideology of the text commissioner and/or TT audience. Ideology can be expressed in the text in the foreground or in the background, and it is essential that even if the ideology in the text was expressed in the background by the author, it will be received in the foreground by the reader if the latter belongs to a different ideological context. What is observed in this case is not a shift in the ideology itself but a shift in its role in the text.

It is somewhat surprising that translation scholars dwell extensively now on the notion of intersemiotic translation introduced by Roman Jacobson sixty years ago. Strange as it might seem, the fact can be easily explained by, first, the greater role of visual audio perception nowadays and, second, by the expansion of screening or staging literary works, which implies interpretation of verbal signs by means of non-verbal ones. The paper by Olga Leontovich may serve as an example of the keen interest of translation scholars to the problems of intersemiotic translation and to the mechanisms used in it. Based upon in-depth analysis of many examples of screening Russian classics for foreign audiences (English, Chinese, Indian, etc.), the article testifies to the fact that what is traditionally called audiovisual translation becomes a very important activity together with audio description as a more marginal translation activity. The author proceeds from the premise that every translation is primarily a form of interpretation of the macromeanings of the source text with the aim of rendering them in another text. She demonstrates that in the process of intersemiotic translation transformations inevitably occur, 
and the text components building up the macromeaning are redistributed in the screened or staged version of the work. This can be conditioned by extralinguistic factors mentioned in the article as commercial, creative and ideological goals of directors. And here I would like to note a flaw in the author's reasoning. She argues that a research of intersemiotic translation should show its impact on social reality. At the same time, the analysis made demonstrates that the social reality influences intersemiotic translation and its mechanisms dramatically. Suffice it to recall that all forms of resignifying mentioned in the article are conditioned by the directors' desire to make a movie as understandable to the target audience as possible or to express creativity of their own. The mere choice of such translation strategies as foreignization, domestication and universalization is predetermined by extralinguistic factors. Yet, the final conclusion of the author is unquestioned: an adaptation is good when it manages to express the macromeaning and to preserve the spirit, values and essence of the original.

The article by Natalia V. Shchurik and Vera E. Gorshkova also confirms that scholars are very much concerned with problems of intersemiotic translation. At the same time it testifies to the fact that interdisciplinary approach can be applied to the investigation of the peculiarities of intersemiotic translation. In particular, the research shows that the notions of the surface structure and the deep structure the content of which is inverted in the paper are applicable. Similar to the previous article, this paper proves that screening of folk fairy-tales is a variety of intersemiotic translation, "interpretation of interpreted" (Garbovsky 2008, 34). The authors argue that elementary plots of the surface structure build up the fairy-tale narrative and are developed in plans, scenarios and frames of the deep structure that are different in British and Russian fairy-tales. It is concluded that national peculiarities that determine the appurtenance of a fairy-tale to a certain culture are encoded in the deep structures of the fairy-tale discourse.

Two previous articles convince us that problems of audiovisual translation are most topical in modern Translation Studies. These problems are also discussed in the article by Vladislav Anisimov, Anna Borisova and Grigoriy Konson that highlights various strategies of localization of titles of French movies translated for the Russian audience as well as the degree of the localization adequacy. The authors argue that localization of a movie implies both translation of the text and its adaptation to the target culture, i.e. transfer from one language code to another. It is concluded that regardless of a translation strategy, the translated title must conform to the plot, theme and content of a movie while the movie itself must be interesting and attractive for the foreign audience.

Traditional problems of reproducing characteristic features of literary texts in translation, although they seem to be purely technical, still are of great interest for translation scholars and linguists, and always will be. Because reproduction of the source text in its entirety, creation of the functional analogue of the ST is next to impossible if the said problems are not solved in each act of translation. The idea is illustrated by the article of Natalia Nesterova and Evgenia Naugolnykh that discusses deformations of language in James Joyce's works and probable methods of their rendition into Russia. The conducted survey proves that multilingualism that is so typical of Joyce's texts and that is manifested in the use of alien material to coin occasional compound units 
is the main challenge for translators. So far, the problem has not been solved successfully. Its complexity is due to plurality of interpretations of the functions performed by deformed English units and nonce words in a text as well as their meanings.

The article of Rafael Guzmán Tirado highlights translation problems posed by linguistic and speech units with a cultural component, i.e. the units closely related to the source culture (realia, idioms, metaphors, comparisons, etc.). For Translation Studies these problems are not novel, at least since the moment that has been defined by SnellHornby as the "cultural turn" (Snell-Hornby 2006). Still it is very fruitful and expedient to consider the dependence of the translator's decision on the peculiarities of the target culture and the distance between the two cultures clashing in the translation process, both in Translation Studies and in translators' practical activity, regardless of how we treat the notion of culture. Tirado's article is of both theoretical and practical importance: using the material of his translation of Evgeny Vodolazkin's novel "Aviator" from Russian into Spanish, he demonstrates that the emotional effect felt by the source text readers can be lost in translation to some extent, and concludes that a translator needs to make drastic interventions in the text to ensure some kind of similarity between the communicative effects produced by the ST and the TT. The author does not confine himself to consideration of instances when realia is used in the ST (those problems have been discussed in Translation Studies abundantly and in detail; moreover, they are solved quite successfully in translation). He argues that the cultural component of the meaning or, to be more exact, of the sense rendered by the text segment being translated is conditioned by the peculiar world outlook and world perception of representatives of the source culture, by their peculiar mentality and ethnic identity.

I have already noted the diversity of fields within Translation Studies which still includes investigation of characteristic features of religious translation. The persistent interest of scholars to this type of translation which once used to be the main translation activity is substantiated by two articles published in this issue. The first article written by Georgy Khukhuni, Irina Valuitseva and Anna Osipova discusses the peculiar features of cultural words (realia) in the Old and New Testaments and peculiarities of their translation. Analysis of a large number of sources enables the authors to make conclusions that disclose both peculiarities of realia and their functioning in the Bible and specifics of their rendition conditioned by extra-linguistic factors. These factors include the choice of the original, the influence of the tradition of translating the Bible in the given culture, the orientation of the translated text to a specific audience (missionary translation), the goal of translation and the impact of certain translation theories on those who are engaged in translation. It implies that religious translation, similar to other types of translation, is always made in accordance with the so called conventional norm (Komissarov 1990: 231-232), i.e. the society's views concerning the tasks of translation activity prevailing in the given epoch.

The second paper on religious translation published by Ibrahim I.I. Najjar, Soh Bee Kwee, Thabet Abu al-haj addresses another specific problem, namely, the issue of preserving the mode of an utterance in English translations of the Quran. The authors investigate what roles are played by rhetorical questions in the text of the Quran and 
what translation shifts occur in its two English translations. The investigation is based on Larson's (Larson 1974: 14) premise that the communicative situation and the attitude of the speaker relate to the grammatical forms used as well as on Wilss's (Wilss 1982: 71) premise that if the context of situation changes, "changes will inevitably take place in the linguistic texture. Conversely, if a shift is carried out on the linguistic level, this context of situation will also change." Accordingly, the mode of an utterance also changes. Analysis of many examples of the use of rhetorical questions in Quran and in its two English translations convince the authors that translation shift, i.e. changes in grammatical forms of rendering rhetorical questions, do occur, although to different extents, and distort the mode of the ST rhetorical questions. Specific as it might be, the issue discussed is relevant to the global problem of the translator's being loyal to the ST sender: the message contained in the ST must be communicated correctly to the readership of the TT, especially in religious translation.

Perhaps, one of the most striking signs of our times manifested in Translation Studies is evolving of the feminist movement (see Prunč 2015), representatives of which insist on political correctness even when it is not intended by the ST Sender. Attempts of some theologists to replace gender-specific linguistic forms by gender-neutral ones in the texts of messianic Scriptures seem to be the most "outstanding" manifestation of political correctness in translation. The article by Konstantin Sharov that uses the material of modern English translations of the Bible discusses such attempts and their consequences. In this case we can speak only about intralingual translation, as it was termed by Roman Jacobson (Jacobson 1957; Jacobson 1975). The author concludes that gender-neutral language introduces new feminist meanings into Messianic sacred texts, which were not previously contained there, and gender-neutral English translations of the Bible cannot be treated as canonical since the original meanings of the Bible can be distorted completely. Thus, from the perspective of the traditional theology the attempts to affirm the social equality of genders in translation of the Holy Scripture can hardly be justified. At the same time the author argues that investigation of gender-neutral strategies allows tracing the evolution of Christian homiletic genre.

New trends in translation generated by the wide use of information technologies (see article by Ives Gambier in the present issue) are discussed in detail in the article by Irina Ovchinnikova. The paper focuses on translation errors that result from the use of computer-assisted translation (CAT) systems, in particular, SmartCat platform. The article does not confine itself to the analysis of types of errors, the more so they turn to be the same as in translation without CAT systems. What matters here is the combination of usual translation errors with incorrect versions suggested by the MT system, which seems to be a specific feature of computer-aided translation. The article also aims at disclosing the causes of translation errors related to the use of SmartCat platform. Based on a thorough analysis of translation errors made in a translation project and their causes, the author concludes that application of CAT systems and machine translation requires a translator to have some additional competences to be able to control the whole text of translation. Moreover, investigation of translation errors will enable CAT systems developers to improve these tools together with their interface. 


\section{CONCLUDING REMARKS}

The presented review testifies to the fact that Translation Studies today are practiceoriented and are more focused on understanding the objective laws of translation activity than in the past. Translation Studies as a science is of inter-disciplinary character, which is predetermined by the complex nature of all types of translation, of the translation activity as a whole. At the same time modern Translation Studies can serve as a basis for didactics of translation, the need of which is extremely urgent now.

A new section is introduced in the present issue to give the floor to experienced translators and interpreters reputed internationally for their achievements in the profession. The interviewees represent different fields of translation activity, which is evident from their responses. Henry Liu is the man who has contributed much to acquiring a higher social standing by the translators' profession. He was very instrumental in the adoption of the UN General Assembly Resolution 71/288 in recognition of 30th September as the International Translation Day (ITD). He is the $13^{\text {th }}$ President of the International Federation of Translators (FIT) and presently Honorary Advisor to the Federation. Boris Naimushin is an experience interpreter, since 2009 an interpreter for the Presidency of Bulgaria. He is actively engaged in the education activity in Bulgaria, Russia and other countries. Victor Lanchikov, professor of School of Translation and Interpreting of Moscow State Linguistic University, is a well-known translator of English literature and initiator of many translation projects. As Editor-in-Chief of the Bridges journal (R.Valent Publishers, Moscow), he does a lot to disseminate professional knowledge about translation in Russia. Irina Zubanova, Associate Professor of Moscow State Linguistic University, is an experienced simultaneous interpreter, a member of the Union of Translators of Russia (UTR) and National Translators League. She has written very interesting works on problems of interpreting, and does a lot to improve training of translators/interpreters in Russia actively participating in Summer and Winter Schools of translation and other events held by UTR. The interviews published in the issue illustrate vividly the problems and issues faced by translators/interpreters in their everyday activity and conceptualized by translation scholars.

\section{$\mathrm{Ru}$}

\section{1. ВВЕДЕНИЕ}

Известно, что переводоведение утвердилось в статусе научной дисциплины во второй половине XX века. Это был вполне закономерное явление, обусловленное, прежде всего, потребностями осмысления особенностей и закономерностей переводческой деятельности, существенно изменившейся к тому времени и расширившей свои границы. Понятно, что эта научная дисциплина создавалась не с чистого листа, а на основе концепций, возникших в предшествующие эпохи. Сама переводческая мысль, бившаяся в сознании переводчиков в разных странах и в разные временные периоды, подготовила формирование, в определенном смысле - оформление разрозненных взглядов на перевод в нечто единое, обретшее со временем форму научного направления. Очевидно, что в предшествующие 
периоды переводческие идеи касались преимущественно двух основных разновидностей переводческой деятельности, доминировавших на протяжении столетий, а именно перевода сакральных текстов, то есть религиозного перевода, и перевода художественного. Не случайно первым и основным направлением переводоведческих исследований, если определение «переводоведческий» вообще применимо к исследованиям перевода в, так сказать, донаучную эпоху, было направление литературоведческое. И только начиная с 30-х годов ХХ века исследователи обратились к изучению проблем специального, то есть нехудожественного и нерелигиозного перевода, что было связано с расширением международного сотрудничества в научно-технической, военной и дипломатической сферах и, соответственно, с потребностями подготовки переводчиков для данных сфер (Сдобников, Петрова 2006: 54 -55). Интерес лингвистов того времени к сопоставительному изучению языков в синхронии способствовал появлению лингвистического направления в исследовании перевода. Как пишет Э. Гентцлер, именно лингвистика способствовала появлению дисциплины, располагавшей теоретическими и языковыми инструментами, необходимыми для создания системного подхода к переводу (Gentzler 1990: 67). Ученых-лингвистов интересовали особенности соотношения разных языков, сталкивающих в процессе перевода, влияющие на ход и результат переводческого процесса. Это был своего рода «поворот» от литературоведения к лингвистике, приведший в результате к противостоянию и даже ожесточенной борьбе двух направлений, по крайней мере, в России. Результатом этой борьбы стало признание того, что даже в области художественного перевода лингвистические факторы играют существенную роль на обоих основных этапах переводческого процесса, то есть в процессе интерпретации оригинала и в процессе порождения перевода (Ларин 1962: 3). Таким образом, примирение двух подходов к переводу состоялось. Но это был лишь начальный период становления и развития переводоведения как науки. Далее мы рассмотрим основные события в его истории и в истории переводческой деятельности, с которой переводоведение непосредственно связано, приведшие к обретению им его нынешнего состояния.

\section{2. ПОВОРОТЫ В ПЕРЕВОДОВЕДЕНИИ}

\section{1. Культурный поворот}

Дальнейшая история переводоведения отмечена несколькими важными «поворотами» (shifts), как они были названы западными учеными (Snell-Hornby 2006). Мы отметим лишь отдельные, наиболее важные моменты, определившие состояние переводоведения на современном этапе. Тех, кто нуждается в более подробной информации о путях развития переводоведения, мы можем отослать к работам, специально посвященным этому вопросу (Gentzler 1990; Prunč 2007; Прунч 2015).

Исходя из того, что всякий поворот предполагает изменение направления, вектора движения, следует отметить то направление, которое послужило начальной точкой отсчета для последующего развития науки о переводе. Вполне естественно предположить, что таким направлением, в соответствии с логикой развития событий, было именно лингвистическое, зародившееся на этапе становления теории перевода как науки. Если обозначить его суть кратко, то можно сказать, 
что в его рамках в качестве основной задачи рассматривалось изучение условий установления отношений эквивалентности между двумя текстами на разных языках, а также факторов, способствующих или препятствующих этому. Не случайно то, что мы в российском переводоведении называем лингвистическим подходом к переводу или просто лингвистическим переводоведением, на Западе именуют подходом, ориентированным на эквивалентность, или парадигмой эквивалентности (Гамбье 2016б). С течением времени пришло осознание ограниченности этого подхода. Как пишет Ив Гамбье, он «...не позволяет рассмотреть, описать и объяснить процесс принятия переводческих решений и результат перевода. Различие между тем, что явно (буквально, непосредственно, лежит на поверхности), и тем, что скрыто (имплицитно, сопряжено с коннотациями, подразумевается), ведет к неверному восприятию процесса перевода, а интерпретация переводчиком содержания оказывается делом весьма непонятным» (Гамбье 2016а: 58-59).

Переводоведение не могло оставаться долго в тисках лингвистического подхода, тем более что сама природа переводческой деятельности подталкивала ученых к включению в круг исследований вопросов, связанных с воздействием на перевод факторов культуры. Осознание того, что перевод - это не только столкновение языков, но и столкновение культур (фраза, сегодня звучащая как аксиома), кардинально изменило сам характер переводоведческих исследований. Как писал А.Д. Швейцер, «столкновение двух культур при переводе происходит и на коммуникативном уровне, и на уровне текста» (Швейцер 1988: 52). Поскольку речь уже шла о культурах, то значит и о носителях разных культур, то есть о людях, для которых перевод есть средство обеспечения коммуникации. Таким образом, стало распространенным терминосочетание «межкультурная коммуникация», а в рассмотрении перевода учеными обнаружилось место - до тех пор вакантное - для человека. Произошел «культурный поворот» и «антропоцентрический поворот» в переводоведении.

С 1980-х годов рассмотрению влияния культуры на перевод и влиянию перевода на культуру было посвящено много работ (Bassnett, Lefevere 1998; Bassnett 2005; Cranmer 2015, Gentzler 2001; Hatim, Mason 2005; Katan 2009; Koskinen 2015, Nida 1993; 1996; Toury 1995). Очевидно, что понятие «культурный поворот» чрезвычайно сложно, многомерно и комплексно, так же как и собственно понятие «культура». Это не могло не повлиять на саму направленность переводоведческих исследований, в которых рассматриваются различные аспекты проявления культур и межкультурных различий в разных видах перевода. Подтверждением этому служат опубликованные в данном выпуске статьи, в которых раскрываются механизмы межкультурного взаимодействия посредством перевода, обязательные для учета практиками и изучения теоретиками.

\section{2. Функциональный подход к переводу: путь в будущее}

По нашему мнению, функциональный подход к переводу (в нашей терминологии - коммуникативно-функциональный) восходит к работам Ю. Найды (Nida 1964; Nida, Taber 1969), основателей скопос-теории К. Райс и Х. Фермеера 
(Reiß, Vermeer 1984; 2013) и ученых Лейпцигской школы (Jäger 1975; Kade 1981; Neubert 1973). Впрочем, если исходить из того, что в основе коммуникативнофункционального подхода - обеспечение восприятия смысла оригинального текста его получателями и переводчиком, а также его воспроизведение в тексте перевода, то к числу предтечей данного подхода можно отнести Цицерона, св. Иеронима и даже Петра I (Федоров 1983: 41). В российском переводоведении можно выделить работы З.Д. Львовской (Львовская 1985; 2008), обратившей особое внимание на передачу смысла в интересах определенной аудитории (Sdobnikov 2017).

В настоящее время коммуникативно-функциональный подход к переводу предполагает рассмотрение переводческого события в рамках определенной коммуникативной ситуации с учетом цели осуществления перевода, потребностей и ожиданий реальных или предполагаемых получателей ПТ (потребителей), способа использования переводного текста в рамках предметной деятельности потребителей перевода. В некоторых случаях важен и учет коммуникативной интенции отправителя исходного сообщения и коммуникативного эффекта, производимого оригиналом на соответствующих получателей. Мы говорим «в некоторых случаях», поскольку обеспечение равенства коммуникативных эффектов, производимых ИТ и ПТ, иногда не представляется необходимым и часто вовсе невозможно. Например, перевод выступления, адресованного аудитории исходного языка, в принципе не может оказать аналогичного воздействия на аудиторию перевода. Подобное утверждение противоречит традиционным взглядам на перевод как на процесс, характеризующийся установкой на передачу коммуникативного эффекта первичного текста (Швейцер 1988: 75).

Поскольку учет особенностей коммуникативной ситуации, в которой осуществляется перевод, является необходимым условием постижения переводчиком цели перевода и того, что К. Норд, вслед за своими учителями, называет translation brief (переводческое задание) (Nord 2005: 9-10), возникает потребность в классификации возможных коммуникативных ситуаций с использованием перевода (КСП). Разработанная нами классификация коммуникативных ситуаций включает два типа КСП - ситуации, в которых перевод изначально (то есть в момент создания ИТ) предполагается, и ситуации, в которых перевод изначально не предполагается. Каждый из этих типов включает виды КСП, выделяемые на основе разных критериев: в первом случае - на основе формы взаимодействия разноязычных коммуникантов (презентация, круглый стол, интервью, экскурсия и т.п.), во втором случае - на основе личности инициатора перевода (Сдобников 2015: 73-93; Sdobnikov 2011). Мы утверждаем, что сам характер коммуникативной ситуации определяет цель перевода и позволяет переводчику выбрать соответствующую этой цели стратегию перевода, понимаемую как общая программа осуществления переводческой деятельности с учетом параметров коммуникативной ситуации (Sdobnikov 2011: 1450).

Таким образом, коммуникативно-функциональный подход к переводу предполагает своего рода погружение - как в теории, так и на практике - в определенную коммуникативную ситуацию, осознание переводчиком параметров этой 
ситуации и тех задач, которые должны быть им решены именно в рамках и применительно к данной ситуации. Особую важность он представляет для профессиональной подготовки переводчиков, поскольку позволяет избавиться (и избавить будущих переводчиков!) от ложного представления о переводе как о трансформации одного текста в другой, как о некоей филологической игре с двумя текстами, и внушить будущим специалистам убежденность в том, что перевод - это деятельность, направленная на удовлетворение потребностей людей путем создания текста на переводящем языке с ориентацией на текст оригинала. Именно такой убежденностью будут характеризоваться будущие поколения переводчиков, если коммуникативно-функциональный подход станет для них своего рода господствующей идеологией.

\section{3. Вечные проблемы переводоведения}

В переводоведении по-прежнему уделяется много внимания проблемам, рассмотрение которых началось много веков назад. К их числу относятся, прежде всего, проблемы художественного перевода и проблемы перевода религиозных текстов, о чем свидетельствует, в частности, и тематика некоторых статей, представленных к этом выпуске журнала. Казалось бы, все, что можно было сказать по этому поводу, уже сказано, и добавить больше нечего. Однако это не так. Все дело в том, что само развитие переводоведения следует рассматривать как спиральное движение: на каждом новом витке в сферу внимания переводоведов включаются новые аспекты ранее рассматриваемых проблем и, что более важно, меняются сами подходы к изучению переводческих проблем, меняется угол зрения, под которым это изучение осуществляется. Несомненно, основным и наиболее перспективным подходом к изучению перевода, включая такие его виды, как художественный перевод, является коммуникативно-функциональный подход, что выглядит очень инновационно, особенно по отношению к переводу сакральных текстов. В частности, с данным подходом вполне согласуется задача обеспечения определенного коммуникативного воздействия на читателей переводных версий Библии, учет самого назначения переводов Священного Писания в данной культурной среде и в данную эпоху (см., например, статьи Г.Т. Хухуни, И.И. Валуйцевой, А.А. Осиповой в этом выпуске). Следует с удовлетворением отметить, что коммуникативно-функциональный подход используется теперь в качестве той теоретической основы, которая позволяет приблизить само изучение вечных (и новых) проблем переводоведения к реалиям практической переводческой деятельности, осуществляемой в интересах конкретных (в определенной ситуации) получателей перевода.

\section{4. Переводоведение сегодня: новые тенденции}

Наш краткий анализ современного состояния переводоведения мы завершим рассмотрением новых направлений, тенденций и тем, появившихся в науке о переводе в последние два десятилетия. Разумеется, перечислить все частные вопросы, интересующие переводоведов, вряд ли представляется возможным в рамках 
статьи. Самое главное - это то, что переводоведение уже доказало свою практическую направленность; по сути, все то новое, что появилось в теории перевода, так или иначе связано с изменениями в характере переводческой деятельности как таковой. Ниже мы отметим пунктирно наиболее значимые изменения и их роль в обогащении проблематики переводоведения.

\subsection{1. Развитие теории устного перевода}

Казалось бы, развитие теории устного перевода не является достижением последнего времени. Но следует учитывать, что предыдущий этап развития науки о переводе подарил нам лишь ряд фундаментальных работ, в которых были заложены основы теории устного перевода и намечены дальнейшие направления исследований в этой области (Миньяр-Белоручев 1969; 1980; Чернов 1987; Ширяев 1979). Эти исследования были в значительной степени связаны с господствовавшим тогда сугубо лингвистическим подходом к переводу. В настоящее время в центре внимания ученых - не только вопросы описания самих механизмов осуществления последовательного или синхронного перевода на основе сопоставления разноязычных продуктов устной речевой деятельности, но и изучение лежащих в основе этих механизмов психолингвистических и нейрофизиологических процессов (Moser-Mercer 1978; Moser-Mercer et al. 1998). К числу абсолютно новых тенденций на переводческом рынке относится осуществление «сольного» синхронного перевода, то есть перевода, осуществляемого синхронистом без напарника. В этом направлении ведутся определенные эмпирические исследования, хотя основательных теоретических работ, посвященных этому вопросу, пока не написано.

\subsection{2. Изучение аудиовизуального перевода}

Расширение сферы использования аудиовизуального перевода (АВП), то есть перевода кинофильмов, видеопрезентаций, компьютерных игр, приложений к смартфонам и т.п., не могло не привлечь внимания переводоведов (Горшкова 2006; 2017; Матасов 2009; Малёнова 2017; Chaume 2016; Díaz Cintas 2009; Gambier 2008). Многими авторами АВП рассматривается как особый вид переводческой деятельности, отличный от устного перевода и письменного перевода (Козуляев 2013). В рамках этого направления исследований можно выделить две сферы. Первая изучение характерных особенностей АВП и отдельных технологий АВП, таких как овервойс, дублирование, субтитрирование (Gottlieb 2009; Pettit 2009). Вторая изучение частных переводческих проблем, возникающих в процессе аудиовизуального перевода, прежде всего, кино- видеоперевода (передача названий фильмов, каламбуров, метафор и т.п.). Радует то, что при рассмотрении этих частных проблем исследователи отказываются от текстоцентрического подхода (Малёнова 2017: 40 - 41) и обращаются к коммуникативно-функциональному, а по сути, полидисциплинарному подходу (Там же), подтверждением чему, в частности, являются опубликованные в данном выпуске статьи О.А. Леонтович, а также Н.В. Щурик и В.Е. Горшковой. Представление об особом характере аудиовизуального перевода как вида переводческой деятельности основано на учете его полисемиотического 
характера (Козуляев 2013; Малёнова 2017; Díaz Cintas 2009), что предполагает изучение АВП и как разновидности интерсемиотического (межсемиотического) перевода, и как способа оказания определенного воздействия на не менее определенную аудиторию.

\subsection{3. Перевод и локализация}

Очевидная технологизация переводческого процесса, использование перевода при создании таких продуктов, как компьютерные игры, приложения к смартфонам, интерфейсов сайтов и т.п., привели к разграничению собственно перевода и так называемой локализации на практике и к появлению новых парадигм изучения перевода в теории (Гамбье 2016а; Gambier 2016б). Например, Энтони Пим утверждает, что новые информационные технологии - это не просто дополнительные инструменты, а системы, «меняющие саму природу когнитивной деятельности переводчика, социальные отношения и профессиональный статус переводчика (перевод мой. - B.C.)» (Руm 2011). Использование локализации вызвано потребностью «изменять функции и характеристики приложений таким образом, чтобы они отвечали требованиям местных потребителей» (Gambier 2016б). Локализация определяется как «процесс модификации продуктов и услуг с целью учета различий на разных рынках (перевод мой. - B.C.)» (LISA 2003: 13). Локализация продукта для иной культурной среды предполагает решение проблем трех типов: лингвистических, культурологических и технических. Примером культурологической проблемы является приведение содержания программного обеспечения для бухгалтерского учета в соответствие с принципами бухгалтерского учета, принятыми в стране использования этого программного продукта. К техническим проблемам можно отнести использование особых технических функций, необходимых для поддержки языков, на которые осуществляется перевод. Таким образом, локализация непосредственно связана с переводом, но шире перевода и предполагает осуществление особых действий технического характера, необходимых для адаптации текста к потребностям носителей иной культуры.

Вместе с тем мы считаем необоснованным противопоставление локализации собственно переводу. К сожалению, подобная тенденция имеет место, по крайней мере, в теории и в переводческом бизнесе. Перевод рассматривается некоторыми менеджерами переводческих компаний как простое преобразование одного текста в другой, замена знаков одного языка знаками другого. Под локализацией подразумевается процесс, в ходе которого осуществляется существенная культурная (прагматическая) адаптация текста к реалиям принимающей культуры (Fridge). При этом дело представляется так, будто в процессе перевода никакая культурная адаптация не осуществляется (Там же). Это, разумеется, не так. Мы прекрасно знаем, что практически всякий перевод предполагает культурную адаптацию текста, осуществление прагматической адаптации (Комиссаров 1990: 211-215), особенно перевод публицистических, художественных, рекламных текстов и даже текстов специальных. Следовательно, локализация отличается от собственно перевода прежде всего использованием определенных технических средств, необходимых для создания продукта в соответствии с требованиями местного рынка. 
Из вышеизложенного также следует, что переводоведение должно более четко определить место и роль перевода в процессе локализации и место локализации в структуре переводческой деятельности.

\section{3. КРАТКИЙ ОБЗОР СТАТЕЙ ВЫПУСКА}

В своей статье Кристиане Норд рассматривает лингвистические особенности заглавий книг и возможные способы их перевода. На первый взгляд, эти вопросы относятся к числу сугубо технических и не нуждаются в каком-либо теоретическом обосновании. Однако то, что автор обсуждает эти конкретные проблемы с точки зрения функционального подхода к переводу, доказывает, что всякая переводческая проблема может рассматриваться в широком контексте, на основе определенного теоретического подхода. Известно, что Кристиане Норд - преданный ученик Ганса Фермеера и Катарины Райс, основоположников скопос-теории (Reiss, Vermeer 1984); кроме того, она внесла значительный вклад в развитие функционального подхода к переводу (Nord, 1991). Одно из наиболее существенных положений скопос-теории заключается в том, что переводческая деятельность должна быть ориентирована на аудиторию принимающей культуры и должна осуществляться в соответствии с переводческим заданием. Данный подход усматривается в рассуждениях автора обо всех аспектах указанной проблемы. Например, говоря о таких параметрах текстуальности, как когезия, когерентность, интенциональность, приемлемость, информативность, ситуационность и интертекстуальность, К. Норд утверждает, что читатели произведений должны иметь определенный опыт ознакомления с заглавиями книг, чтобы воспринять заглавие как некое приглашение к коммуникации по поводу данного текста и понять содержащуюся в заглавии информацию. Интенциональность означает, что авторы текста обычно имеют определенную коммуникативную интенцию. Приемлемость подразумевает готовность получателей текста воспринять его смысл. Информативность заглавия подразумевает его способность вызвать у читателей интерес к тексту. Можно сделать вывод, что за каждым переводческим актом, а точнее, внутри каждого переводческого акта просматриваются фигуры создателя оригинала и получателей перевода. Результат переводческого акта определяется коммуникативной интенцией автора оригинала, потребностями получателей перевода и, в конечном итоге, целью перевода. К. Норд делает вывод, что поскольку заглавие - это текст о другом тексте, оно должно рассматриваться в качестве метатекста. Но в то же время оно связано определенными отношениями с основным текстом, без которого не может выполнять свою функцию заглавия. Будучи инструментом коммуникации, заглавие выполняет следующие функции, указанные в статье: отличительную (мы могли бы, вслед за Р. Якобсоном, назвать ее денотативной), референциальную, экспрессивную, фатическую, апеллятивную. Сама композиция соответствующего раздела статьи содержит намек на то, что все эти коммуникативные функции заглавий должны быть воспроизведены в переводе. Для этого переводчик должен осознать ситуационность заглавия, определяемую такими экстралингвистическими факторами, как способ, время, место и мотив создания и восприятия заглавия. При переводе заглавий ориентация на аудиторию и на функции чрезвычайно 
важны, поскольку перевод заглавия должен выполнять необходимые функции в общем корпусе заглавий в принимающей культуре и одновременно сохранять верность по отношению к оригинальному названию. В итоге автор приходит к выводу, что методика, использованная для анализа проблем перевода заглавий, может служить определенной парадигмой при осуществлении перевода текстов иных типов.

В статье Ива Гамбье представлена широкая картина изменений как во взглядах на сущность перевода как деятельности и профессии, так и на роль перевода и потребность в нем в прошлом и в современную эпоху. Прежде всего, автор утверждает, что перевод не является единственной формой межкультурного взаимодействия, а сосуществует наряду с другими формами взаимодействия (люди могут изучать иностранные языки и, соответственно, обходиться без перевода; языки могут сосуществовать в виде билингвизма; в разные эпохи и в настоящее время существуют так называемые lingua franca). Далее, интерес представляют рассуждения автора об отрицании потребности в переводе, об отрицании перевода как деятельности, требующей определенных усилий и умений, и об отрицании перевода как профессии. Важно отметить, что те, кто отрицает перевод как деятельность, требующую определенных усилий, придерживаются наивного взгляда на перевод, согласно которому перевод - это всего лишь замена слов одного языка словами другого языка, замена, которая может быть осуществлена любым субъектом, даже не имеющим специальной подготовки. Отрицание перевода как профессии предполагает взгляд на переводчика как на некоего отшельника либо обманщика, а не как на посредника. По мнению автора, до сих пор весьма распространенным является и отрицание перевода как учебной и научной дисциплины, в результате чего в рамках многих университетских образовательных программ теория перевода до сих пор не обрела достойного ее места.

Ив Гамбье уделяет значительное внимание изменениям в переводческой деятельности, вызванным распространением новых информационных технологий, и показывает, что широкое применение различных технологических инструментов создает у пользователей переводом иллюзию, что перевод - это деятельность, осуществляемая практически мгновенно, без каких-либо усилий. Здесь важно отметить и то, что появление, скажем, облачных технологий, а также обмен данными в режиме реального времени значительно упрощают работу переводчиков и менеджеров и сокращает расходы. При этом отмечается, что в реальной жизни обозначилось разделение между профессиональным переводом, в процессе которого переводчики могут объединяться в команды и обмениваться данными, используя системы автоматизированного перевода, и непрофессиональным переводом (фанатский перевод, перевод, осуществляемый волонтерами). С этой же темой связаны и рассуждения автора об особенностях глобального, региональных и национальных рынков переводов.

Говоря об особенностях переводческой деятельности вообще, Ив Гамбье отмечает, что в последнее время в употребление вошло большое количество обозначений видов перевода, появившихся сравнительно недавно. Наряду с термином 
«перевод» в переводческом дискурсе употребляются термины «локализация», «адаптация», «транскреация» и другие. Причем перевод часто противопоставляется указанным видам переводческой деятельности, а иногда и отрицается как нечто необходимое. Это противопоставление основано на ложном представлении o «переводе», который мыслится как последовательная замена знаков одного языка знаками другого языка, хотя в последнее время представление о творческом характере перевода возвращается в переводоведение. Это многообразие обозначений (labels) для видов перевода нарушает стабильность самой теории перевода, ибо объект изучения оказывается весьма неопределенным.

В своей статье Ив Гамбье делает вывод, что в настоящее время в рамках переводоведения наблюдаются две парадигмы: первая основана на традиционных теориях эквивалентности, постепенно модифицирующихся под влиянием «культурного поворота»; вторая отражает особенности цифровой культуры. Неизбежно возникает вопрос: превратится ли переводоведение в по-настоящему интердисциплинарную науку или мы станем свидетелями появления множества разных дисциплин (теория адаптации, теория трансфера, управление знаниями, теория посреднической деятельности)? Автор утверждает, что вместо того, чтобы поглощать смежные дисциплины, теория перевода должна признать сложный характер коммуникации и поведения людей.

Марта Казьмерчак обращается к проблеме передачи маркеров интертекстуальности в переводе поэтических текстов. Хотя эта проблема вряд ли может считаться новой и к тому же получила широкое освещение в переводоведческой литературе, статья может считаться в определенной степени инновационной, во-первых, благодаря подходу, который использует автор при рассмотрении проблем передачи интертекстуальности, а во-вторых, благодаря сделанным наблюдениям и выводам. Особенность используемого подхода состоит в рассмотрении проблем, возникающих при переводе маркеров интертекстуальности, применительно к языкам и культурам, находящимся друг от друга на значительном расстоянии (в данном случае речь идет об английской и польской культурах). В статье рассматриваются референты исходной культуры, плохо известные в мире, что представляет собой, по мнению автора, сферу особого противодействия осуществлению перевода. В статье делается акцент на важности степени эксплицированности интертекстуальных связей с точки зрения переводчика и на степени узнаваемости маркеров интертекстуальности. Несомненно, Марта Казьмерчак придерживается функционального подхода к переводу: поскольку маркеры интертекстуальности выполняют в исходном тексте определенные функции, они должны быть воспроизведены в переводе так, чтобы вызвать определенную реакцию со стороны получателей перевода. Автор анализирует основные факторы, которые могут воспрепятствовать узнаванию получателями интертекстуальных связей, при этом одним из самых главных является низкая узнаваемость референтов исходной культуры. Автор утверждает, что в основе такой низкой узнаваемости лежит «дисбаланс» влияния разных культур, с которых и на которые осуществляется перевод. Отметим следующие наблюдения, касающиеся передачи интертексту- 
альности в переводе. Прежде всего, автор указывает на то, что даже сложно воспринимаемый получателями перевода маркер может служить сигналом наличия интертекстуальности. Например, воспроизведенное в переводе иностранное имя может быть более сильным маркером интертекстуальности, чем привычное для получателей перевода, семантически прозрачное имя. А постраничные сноски имеют ограниченную применимость, особенно в области поэтического перевода. Самый же главный вывод автора заключается в следующем: четкое представление о получателе, его культурной компетентности и потребностях определяют стратегию перевода, особенно в процессе воспроизведения интертекстуальности. Другими словами, успешный перевод интертекстов возможен, если переводчик видит свою задачу в выравнивании уровней знаний получателей оригинала и получателей перевода.

Статья Н.В. Яркиной, Л.П. Яркиной и И.А. Пугачева замечательна тем, что в ней предпринимается попытка рассмотреть ситуации, в которых перевод осуществляется в условиях столкновения идеологий аудитории ИТ и аудитории ПТ. Авторы определяют идеологию как совокупность убеждений и ценностей, разделяемых определенной социальной группой. Идеология оказывает воздействие на всех, кто вовлечен в процесс перевода, и оказывает влияние на деятельность переводчика. Авторы утверждают, что используемый ими подход к переводу как к межгрупповому посредничеству в процессе передачи идеологического компонента помогает найти адекватный способ выражения авторского послания в условиях идеологического конфликта. В статье делается попытка дать ответ на вопрос, в каких условиях идеологически обусловленное вмешательство переводчика может рассматриваться как желательное и оправданное, а также какие факторы определяют переводческое решение, в частности, приводящие к идеологическим сдвигам. Под «идеологическим сдвигом» авторы подразумевают ситуации, в которых идеологически окрашенный элемент исходного текста преобразуется в переводном тексте таким образом, что он перестает выражать идеологию исходного текста, или, наоборот, в переводной текст вносится идеологически окрашенный элемент, выражающий идеологию, отсутствовавшую в исходном тексте. В статье рассматриваются проблемы, возникающие в ситуациях, в которых исходный текст выражает идеологию, противоречащую идеологии заказчика перевода или получателей переводного текста. Идеология может выступать в тексте на передний план или оставаться на заднем плане, и важно то, что даже если идеология была выражена автором на заднем плане, для читателя она будет выступать на переднем плане, если он находится в ином идеологическим контексте. В этом случае мы наблюдаем не идеологический сдвиг как таковой, а сдвиг в ролях, выполняемых идеологией в тексте.

Сегодня немного удивляет тот факт, что переводоведы активно обсуждают понятие «интерсемиотический перевод», введенное в обиход Р. Якобсоном вот уже шестьдесят лет назад. Как бы странно это ни казалось, этому обстоятельству есть объяснение: во-первых, в современную эпоху значительно возросла роль визуального и аудиального восприятия действительности, во-вторых, увеличилось 
количество экранизаций и инсценировок литературных произведений, что предполагает интерпретацию вербальных знаков при помощи невербальных. Примером острого интереса переводоведов к проблемам интерсемиотического перевода и к используемым в его процессе механизмам является статья О.А. Леонтович. Основанная на глубоком анализе большого количества экранизаций русской литературной классики для иностранной аудитории (англоязычной, китайской, индийской и т.д.), она служит подтверждением того, что вид перевода, который уже традиционно именуется аудиовизуальным, обретает особую важность, наряду с аудио-дескрипцией, более маргинальным видом переводческой деятельности. Автор исходит из того, что всякий перевод есть прежде всего интерпретация макросмыслов исходного текста с целью воспроизведения их в форме текста на ином языке. Она показывает, что в процессе интерсемиотического перевода неизбежно происходят трансформации, и компоненты текста, формирующие макросмысл, перераспределяются особым образом в фильме или сценической постановке. Это определяется экстралингвистическими факторами, которые в статье обозначаются как коммерческие, творческие и идеологические цели режиссеров. И здесь хотелось бы отметить одно противоречие в рассуждениях автора. О.А. Леонтович утверждает, что изучение интерсемиотического перевода должно раскрыть его влияние на социальную реальность. Но в то же время проведенный ею анализ свидетельствует о том, что, скорее, социальная реальность оказывает сильное воздействие на интерсемиотический перевод и на используемые механизмы. Достаточно вспомнить, что использование всех видов переозначивания, упоминаемых в статье, определяется желанием режиссеров сделать фильм как можно более понятным целевой аудитории либо выразить свою собственную креативность. Даже выбор таких стратегий перевода, как форенизация, доместикация и универсализация, обусловлен действием экстралингвистических факторов. Тем не менее, итоговый вывод автора не подлежит сомнению: адаптация литературного произведения удачна, если в ней выражается макросмысл оригинала и сохраняются дух, ценности и суть оригинала.

Еще одним подтверждением интереса ученых к проблемам интерсемиотического перевода является статья Н.В. Щурик и В.Е. Горшковой, которая, в то же время, свидетельствует о возможности изучения этих проблем с использованием интердисциплинарного подхода, в частности, рассмотрения особенностей интерсемиотического перевода в терминах поверхностной и глубинной структур Н. Хомского. При этом содержание этих понятий в статье инвертируется. Как и в предыдущей статье, экранизация волшебных сказок, а именно они и являются материалом исследования, выступает в качестве интерсемиотического перевода, «интерпретации интерпретированного» (Гарбовский 2008: 34). Авторы утверждают, что сказочный нарратив отображается элементарными сюжетами поверхностной структуры, а функциям поверхностной структуры соответствуют планы, сценарии и фреймы глубинной структуры, которые заметно различаются, к примеру, в британских и русских волшебных народных сказках. Проведенный анализ позволяет сделать вывод, что национальные различия, которые определяют принадлежность 
той или иной народной волшебной сказки к определенной культуре, закодированы в глубинных структурах сказочного дискурса.

Рассмотрение содержания предыдущих двух статей убеждает нас в том, что проблемы аудиовизуального перевода относятся к числу наиболее актуальных проблем переводоведения в современную эпоху. Этим же проблемам посвящена статья В.Е. Анисимова, А.С. Борисовой и Г.Р. Консона, в которой рассматриваются стратегии локализации названий французских кинофильмов в переводе для русскоязычной аудитории и степень ее адекватности. Авторы доказывают, что в процессе локализации иноязычной киноленты осуществляется не только перевод ее текстовых элементов, но и адаптация к культуре целевой аудитории, т.е. происходит переход от одного языкового и культурного кода к другому. В статье делается вывод, что независимо от выбора переводческой стратегии название должно соответствовать сюжету, тематической направленности и идейно-образному содержанию фильма, при этом фильм должен оставаться интересным и привлекательным для иноязычного зрителя.

Традиционные проблемы воспроизведения особенностей художественного текста в межъязыковом переводе, проблемы, казалось бы, сугубо технологические, по-прежнему интересуют переводоведов и лингвистов и всегда будут интересовать, поскольку без решения этих проблем воссоздание каждого конкретного художественного произведения во всей его полноте, создание полного функционального аналога оригинала не представляется возможным. Подтверждение этого неоспоримого факта мы находим в статье Н.М. Нестеровой и Е.А. Наугольных, посвященной анализу деформации языковых единиц и новообразований в произведениях Дж. Джойса, а также изучению возможных способов их перевода на русский язык. Проведенный авторами анализ свидетельствует о том, что характерное для текстов Дж. Джойса многоязычие, проявляющееся в использовании иноязычного материала для создания сложных слов-окказионализмов, представляет собой основную проблему в процессе перевода, не нашедшую окончательного решения до сих пор. Сложность решения этой проблемы определяется, прежде всего, множественностью интерпретаций не только функций, выполняемых деформированными элементами английского языка и новообразованиями, но и возможных значений подобных единиц.

Статья Рафаэля Гусмана Тирадо посвящена рассмотрению проблем, возникающих при переводе языковых и речевых единиц, содержащих культурный компонент, то есть имеющих тесную связь с исходной культурой (реалии, идиомы, метафоры, сравнения и т.п.). Для переводоведения эти проблемы не являются новыми, по крайней мере с того момента, который был обозначен М. СнеллХорнби как «культурный поворот» (cultural turn) (Snell-Hornby 2006). Независимо от того, как мы трактуем понятие «культура», обращение к рассмотрению зависимости переводческого выбора от особенностей принимающей культуры, от величины дистанции между исходной культурой и культурой принимающей, имеет большое значение как для переводоведения, так и для практики перевода. Статья имеет помимо теоретической еще и практическую направленность: на примере 
собственного перевода романа Евгения Водолазкина «Авиатор» на испанский язык автор показывает, что эмоциональный эффект, ощущаемый читателем оригинала, в определенной степени утрачивается в переводе. В статье делается вывод, что от переводчика требуется существенное «оперативное вмешательство» в художественный текст с целью обеспечить хотя бы приблизительное равенство коммуникативных эффектов, производимых двумя текстами. При этом автор не ограничивает себя рассмотрением проблем, обусловленных использованием в оригинале слов-реалий (эти проблемы не только подробно рассмотрены в переводоведческих работах, но и часто решаются на практике вполне успешно). Он показывает, что культурный компонент значения, а если говорить точнее, смысла переводимого сегмента текста часто возникает в связи с особым мировоззрением и мировосприятием представителей исходной культуры, определяется их особым менталитетом.

Выше мы говорили о многообразии направлений переводоведческих исследований, к числу которых по-прежнему относится исследование особенностей религиозного перевода. Неиссякаемый интерес к этому виду перевода, некогда являвшимся практически основным видом переводческой деятельности, подтверждается двумя статьями, опубликованными в данном выпуске. Первая статья написана Г.Т. Хухуни, И.И. Валуйцевой и А.А. Осиповой. В ней рассматривается специфика реалий в текстах Ветхого и Нового Заветов и особенности их перевода. Анализ большого количества источников позволяет авторам сделать очень интересные выводы, свидетельствующие не только об особом характере реалий и их функционирования в текстах Библии, но и о специфике их межъязыковой передачи, связанной с действием экстралингвистических факторов. К числу этих факторов можно отнести сам выбор оригинала, влияние сложившейся в данной культуре традиции перевода Библии, ориентированность перевода на специфическую аудиторию (миссионерский перевод), цель осуществления перевода, а также влияние определенных переводоведческих концепций на деятельность переводчиков. Все это свидетельствует о том, что религиозный перевод, так же как и другие виды перевода, подвержен воздействию со стороны конвенциональной нормы перевода (Комиссаров 1990: 231-232), то есть взглядов общества на задачи переводческой деятельности, доминирующих в ту или иную эпоху.

В статье Ибрахима Наджара, Со Би Кви и Табета Абу Аль-хаи рассматривается другая конкретная проблема религиозного перевода, а именно проблема сохранения модальности высказывания в переводе Корана на английский язык. Авторы анализируют, какие функции выполняют риторические вопросы в тексте Корана и какие грамматические изменения в оформлении риторических вопросов наблюдаются в его двух английских переводах. Исследование основано на положении М. Ларсона (Larson 1974: 14), согласно которому коммуникативная ситуация и отношение говорящего определяют набор используемых грамматических форма, а также на утверждении В. Вилса (Wilss 1982: 71) о том, что если меняется предметная ситуация, «то неизбежно меняется и языковая форма высказывания. И наоборот, если происходят изменения на языковом уровне, то и предметная 
ситуация также меняется» (перевод мой. - B.С.). Соответственно, меняется и модальность высказывания. Анализ большого количества примеров использования риторических вопросов в тексте Корана и в двух английских переводах приводит авторов к выводу, что переводческие сдвиги, то есть изменения грамматических форм при передаче риторических вопросов, действительно имеют место в переводах, хотя и в разной степени, и приводят к искажению модальности риторических вопросов, использованных в оригинале. Каким бы конкретным ни был обсуждаемый вопрос, он имеет непосредственное отношение к глобальной проблеме верности (loyalty) переводчика автору оригинала: содержание исходного текста должно быть верно передано получателям перевода.

Одной из наиболее ярких «примет времени» в современном переводоведении является появление феминистского течения (см., например, Прунч 2015), представительницы которого настаивают на соблюдении политкорректности, даже если она не предполагалась создателем оригинала. Пожалуй, самым «выдающимся» проявлением политкорректности в переводе является стремление некоторых теологов заменить гендерно-специфичные формы гендерно-нейтральными в текстах Священного Писания. Именно анализу подобных попыток и их результатов посвящена статья К.С. Шарова, написанная на материале современных англоязычных переводов Библии. Собственно, если и можно здесь говорить о переводе, то только о переводе внутриязыковом в терминологии Р.О. Якобсона (Jacobson 1957; Якобсон 1975). Проведенный автором анализ свидетельствует о том, что гендерно-нейтральный язык вносит новые феминистские смыслы в мессианские священные тексты, ранее там не содержавшиеся, а гендерно-нейтральные английские переводы христианской Библии перестают быть каноничными с точки зрения христианской теологии, поскольку изначально содержавшиеся в Библии смыслы могут оказаться полностью искаженными. Таким образом, с точки зрения традиционного богословия попытки утвердить социальное равенство полов при переводе Священного Писания вряд ли оправданы. В то же время автор утверждает, что изучение гендерно-нейтральных стратегий позволяет проследить эволюцию жанра христианской гомилетики.

Некоторые новые тенденции в переводческой деятельности, связанные с широким использованием информационных технологий (см. статью Ива Гамбье в настоящем выпуске), обсуждаются в статье И. Г. Овчинниковой. Статья посвящена анализу переводческих ошибок, возникающих в связи с использованием систем переводческой памяти, в частности, на примере платформы SmartCat. Автор не ограничивает себя исключительно анализом типов совершаемых переводчиками ошибок, тем более что они оказываются такими же, как и в переводе без использования систем переводческой памяти. Здесь важно то, что в данном случае имеет место сочетание обычных ошибок с неточностями машинного перевода, что представляется специфической особенностью перевода на основе компьютерных программ. В статье также ставится цель выявить причины переводческих ошибок, связанных с использованием платформы SmartCat. На основе скрупулезного анализа ошибок, совершенных в рамках переводческого проекта группой переводчи- 
ков, а также их причин, автор делает вывод, что использование систем автоматизированного и машинного перевода требует от переводчика наличия дополнительных компетенций, необходимых для того, чтобы контролировать процесс создания текста перевода в целом. В то же время изучение переводческих ошибок сможет помочь разработчикам систем автоматизированного перевода усовершенствовать инструменты САТ и пользовательский интерфейс платформы.

\section{4. ЗАКЛЮЧЕНИЕ}

Представленный обзор свидетельствует о том, что переводоведение в настоящее время имеет практическую направленность, в большей степени, чем ранее, ориентировано на постижение закономерностей переводческой деятельности. При этом переводоведение как наука имеет междисциплинарный характер, что обусловлено комплексным характером практически всех видов перевода, переводческой деятельности как таковой. Одновременно современное переводоведение уже способно служить в качестве теоретической основы для разработки дидактики перевода, потребность в которой ощущается весьма остро.

В данном выпуске представлена новая рубрика «Форум», в которой предоставлено слово опытным переводчикам-практикам с международной репутацией. Интервьюируемые представляют разные сферы переводческой деятельности, что нашло отражение в содержании их ответов на поставленные вопросы. Генри Лью (Henry Liu) - человек, благодаря которому переводческая профессия обрела общественное признание. Благодаря его усилиям Генеральная Ассамблея ООН учредила Международный день переводчика, который мы празднуем ежегодно 30 сентября. Генри Лью - 13-й Президент Международной федерации переводчиков (ФИТ), в настоящее время - Почетный советник ФИТ. Борис Наймушин - опытный устный переводчик, с 2009 года — переводчик Президента Болгарии. Он ведет очень активную просветительскую деятельность не только в Болгарии, но и в России, а также в других странах. Виктор Константинович Ланчиков, профессор переводческого факультета Московского государственного лингвистического университета, известен в России как замечательный переводчик английской художественной литературы, инициатор многих переводческих проектов. Будучи главным редактором журнала «Мосты» (издательство «Р.Валент», Москва), он много делает для распространения профессиональных переводческих знаний в России. Ирина Владимировна Зубанова - доцент Московского государственного лингвистического университета, опытнейший переводчик-синхронист, член Союза переводчиков России и Национальной лиги переводчиков, автор чрезвычайно интересных работ, посвященных проблемам устного перевода. Она многое делает для совершенствования переводческого образования в стране, активно участвуя в Летних и Зимних школах перевода и в других мероприятиях, проводимых Союзом переводчиков России. Интервью коллег служат прекрасной иллюстрацией тех проблем, с которыми сталкиваются переводчики в процессе своей каждодневной деятельности и которые подвергаются теоретическому осмыслению переводоведами.

() Vadim V. Sdobnikov / В.В. Сдобников, 2019 


\section{REFERENCES / СПИСОК ЛИТЕРАТУРЫ}

Bassnett, Susan (2005). Translation Studies. $3^{\text {rd }}$ ed. London and New York, Routledge.

Bassnett, Susan / Lefevere, André (1998). Constructing Cultures. Essays on literary translation. Clevendon-Philaselphia: Multilingual Matters (Topics in translation 11).

Chaume, Frederic (2016). Audiovisual translation trends: growing diversity, choice and enhanced localization. Media across borders. Localizing film, TV and video games. Ed. by A. Esser, M.A. Bernal-Merino, I.R. Smith. New York: Routledge, 68-84.

Cranmer, Robin (2015). Introducing Intercultural Communication into the Teaching of Translation. Russian Journal of Linguistics, 19 (4), 155-174.

Díaz Cintas, Jorge (2009). Introduction - Audiovisual Translation: An Overview of Its Potential. New Trends in Audiovisual. Ed. by J. Díaz Cintas. Bristol; Buffalo; Toronto, 1-18.

Fridge. Available at: http://fridge.com.ua/2011/02/lokalizatsiya-perevoda/.

Gambier, Yves (2008). Recent developments and challenges in audiovisual translation research. Between Text and Image: Updating Research in Screen Translation. Amsterdam; Philadelphia: John Benjamins Publ. Co., 11-35.

Gambier, Yves (2016б). Rapid and Radical Changes in Translation and Translation Studies. International Journal of Communication. Issue 10, 887-906.

Gentzler, Edwin (1990). Contemporary Translation Theory: Dissertation submitted for the degree of Doctor of Philosophy in Comparative Literature. Nashville, Tennessee.

Gentzler, Edwin (2001). Contemporary Translation Theories. Revised $2^{\text {nd }}$ Edition. Clevedon, Multilingual Matters Ltd.

Gottlieb, Henrik (2009). Subtitling against the Current: Danish concepts, English minds. J. Díaz Cintas (Ed.). New Trends in Audiovisual Translation. Bristil; Buffalo; Totonto, 21 - 43.

Hatim, Basil / Mason, Ian (2005). The Translator as Communicator. London, New York: Routledge.

Jacobson, Roman (1959). On Linguistic Aspects of Translation. On Translation. Harvard University Press, Cambridge, Massachusetts.

Jäger, Gert (1975). Translation und Translationslinguistik. Halle (Saale): VEB Max Niemeyer.

Kade, Otto (1981). Probleme des übersetzungswissenschaftlichen Textvergleichs. Leipzig: VEB Enzyklopädie (Übersetzungswissenschaftliche Beiträge 4).

Katan, David. Translation as Intercultural Communication. The Routledge Companion to Translation Studies. Revised edition. Ed. by Jeremy Munday. London, New York: Routledge.

Koskinen, Kaisa (2015). Training Translators for a Superdiverse World. Translators' Intercultural Competence and Translation as Affective Work. Russian Journal of Linguistics, 19 (4), 175184.

Larson, Mildred (1974). The communicative situation and rhetorical questions. Notes on Linguistics, $9,14-18$.

LISA. The Localization Industry Primer. $2^{\text {nd }}$ ed. Available at: https://www.immagic.com/eLibrary/ ARCHIVES/GENERAL/LISA/L030625P.pdf

Moser-Mercer, Barbara (1978). Simultaneous Interpretation: A Theoretical Model and its Practical Application. Gerver, D. et Sinaiko, W.H. Language, Interpretation and Communication. New York, Plenum Press, 353-368.

Moser-Mercer, Barbara, Künzli, Alexander, Korac, Marina (1998). Prolonged turns in interpreting: Effects on quality, physiological and psychological stress. Interpreting, No. 3 (1), 47-64.

Neubert, Albrecht (1973). Theorie und Praxis für die Übersetzungswissenschaft. Linguistische Arbeitsberichte 7, 120-144. 
Nida, Eugene (1964). Toward a Science of Translating. With Special Reference to Principles and Procedures in Bible Translating. Leiden: Brill.

Nida, Eugene / Taber, Charles (1969). The Theory and Practice of Translation. Leiden: Brill.

Nida, Eugene (1993). Language, Culture and Translating. Shanghai: Foreign Language Education Press.

Nida, Eugene (1996). The Sociolinguistics of Interlingual Communication. Bruxelles: Éditions du Hazard (collection Traductologie).

Nord, Christiane (2005). Text Analysis in Translation. Theory, Methodology and Didactic Application of a Model of Translation-Oriented Text Analysis. $2^{\text {nd }}$ ed. Editions Rodopi, Amsterdam New York.

Pettit, Zoë (2009). Connecting cultures: cultural transfer in subtitling and dubbing. J. Díaz Cintas (Ed.). New Trends in Audiovisual Translation. Bristil; Buffalo; Totonto, 44-57.

Prunč, Erich (2007). Entwicklungslinien der Translationswissenschaft. Von den Asymmetrien der Sprachen zu den Asymmetrien der Macht. Frank \& Timme GmbH.

Pym, Anthony (2009). Natural and directional equivalence in theories of translation. The metalanguage of translation. Eds. Y. Gambier, L. van Doorslaer. Amsterdam, Philadelphia, John Benjamins Publ.

Pym, Anthony (2011). What Technology Does to Translating. Translation and Interpreting. Vol. 3. 1(2011). Available at: https://cloud.mail.ru/public/4QBA/ZuUpBXypn/PYM.What technologies does to translating.pdf

Reiss, Katharina / Vermeer, Hans J. (1984): Allgemeine Grundlegung einer Translations theorie. Tübingen: Niemeyer.

Reiß, Katharina / Vermeer, Hans (2013). Towards a General Theory of Translational Action. Skopos Theory Explained / Translated from German by Christiane Nord. Manchester: St. Jerome Publishing.

Sdobnikov, Vadim (2011). Translation Strategy Revised: The Communicative-Functional Approach. Journal of Siberian Federal University. Humanities \& Social Sciences. V. 4 (10).

Sdobnikov, Vadim (2017). Communicative-Functional Approach in Russian Translation Studies: Where Does It Come From? Science Journal of VolSU. Linguistics. 2017. Vol. 16. No. 3.

Snell-Hornby, Mary (2006). The Turns of Translation Studies. New Paradigms or Shifting Viewpoints? Amsterdam/Philadelphia: John Benjamins.

Toury, Gideon (1995). Descriptive Translation Studies and beyond. Amsterdam/Philadelphia: Benjamins (Benjamins Translation Library 4).

Wilss, Wolfram. (1982). The Science of Translation: Problems and Method. Tubingen: Narr.

Гамбье И. Перевод и переводоведение на перекрестке цифровых технологий // Вестник СПбГУ. Серия 9. 2016. Вып. 4 [Gambier, Ives (2016). Perevod i perevodovedenie na perekrestke tsifrovykh tekhnologii (Translation and Translation Studies at the Crossroads of Digital Communications). Vestnik SPbGU. Ser. 9. Vyp. 4 (In Russ.)].

Гарбовский Н.К. Отражение как свойство перевода. Вестник МГУ. Серия 22. Теория перевода. 2008. № 4. C. 26 - 36. [Garbovskiy, N.K. (2008). Otrazhenie kak cvoictvo perevoda (Reflection as a Property of Translation). Vestnik MGU. Ser. 22. Teorija perevoda. № 4. 26-36. (In Russ.)].

Горшкова В.Е. Перевод в кино: монография. Иркутск: ФГБОУ ВПО «ИГЛУ», 2006 [Gorshkova, V.E. (2006). Perevod v kino: monografija (Film Translation: monograph). IGLU (In Russ.)].

Горшкова В.Е. Перевод кинодиалога как осмысленный произвол // Перевод: ремесло, искусство, наука: монография / Под общ. ред. В.Е. Горшковой. Иркутск: Изд-во ИГУ, 2017 [Gorshkova, V.E. (2017). Perevod kinodialoga kak osmyslenny proizvol (Translation 
of Film Dialogue as a Conscious Abuse). Perevod: remeslo, iskusstvo, nauka: monografija. Irkutsk, IGU (In Russ.)].

Козуляев А.В. Аудиовизуальный полисемантический перевод как особая форма переводческой деятельности и особенности обучения данному виду перевода. XVII Царскосельские чтения: мат-ль Междунар. науч. конф-иии, 23-24 апреля 2013 г. СПб., 2013. Т. І [Kozulyaev, A.V. (2013). Audiovizualny polisemantichesky perevod kak osobaja forma perevodcheskoi deyatelnosti I osobennosti obuchenija dannomu vidu perevoda (Audiovisual Polysemantic translation as a specific form of translation activity and methods of teaching it). XVII Tsarskoselskie chtenija: materialy mezhdunarodnoi nauchnoi konferentsii, 23-24 aprelya 2013 goda. Saint-Petersburg (In Russ.)].

Комиссаров В.Н. Теория перевода (лингвистические аспекты). М.: Высшая школа, 1990. [Komissarov, V.N. (1990). Teorija perevoda (Lingvisticheskie aspekty) (Translation Theory (Linguistic Aspects). Moscow, Vysshaja Shkola Publishing House (In Russ.)].

Ларин Б.А. Наши задачи. Теория и критика перевода. Л., 1962 [Larin, B.A. (1962). Nashi zadachi (Our Tasks). Teorija i kritika perevoda. Leningrad (In Russ.)].

Львовская 3.Д. Теоретические проблемы перевода (на материале испанского языка). М.: Высшая школа, 1985 [Lvovskaya, Zinaida (1985). Teoreticheskie problem perevoda (na materiale ispanskogo jazyka) (Theoretical Problems of Translation (on the material of Spanish). Moscow, Vysshaya shkola (In Russ.)].

Львовская З.Д. Современные проблемы перевода: Пер. с исп. М.: Издательство ЛКИ, 2008 [Lvovskaya, Zinaida (2008). Sovremennye problemy perevoda (Modern Problems of Translation). Moscow, LKI Publishing House (In Russ.)].

Малёнова Е.Д. Теория и практики аудиовизуального перевода: отечественный и зарубежный опыт. Коммуникативные исследования, 2017, № 2(12), 32- 46 [Malyonova, E.D. (2017). Teorija i prektika audiovizualnogo perevods: otechestvenny i zarubezhny opyt (Theory and Practice of Audiovisual Translation: Russian and Foreign Experience). Kommunikativnye issledovanija, 2017, No 2(12) (In Russ.)].

Матасов Р.А. Перевод кино/видео материалов: лингвокультурологические и дидактические аспектыл: дис. ... канд. филол. наук. М., 2009 [Matasov, R.A. (2009). Perevod kino/video materialov: lingvokulturologicheskie i didakticheskie aspekty (Translation of Films and Videos: Linguocultural and Didactic Aspects): diss...kand. filol. nauk. Moscow (In Russ.)].

Миньяр-Белоручев Р.К. Последовательный перевод. Теория и методика обучения. М.: Воениздат, 1969 [Minjar-Beloruchev, R.K. (1969). Posledovatelnyi perevod. Teotija i metodika obuchenija (Consecutive Interpreting. Theory and Methods of Teaching). Moscow, Voenizdat (In Russ.)].

Миньяр-Белоручев Р.К. Общзая теория перевода и устный перевод. М.: Воениздат, 1980 [Minjar-Beloruchev, R.K. (1980). Obshchaja teorija peredoda i ustnyi perevod (General Translation Theory and Oral Interpreting). Moscow, Voenizdat (In Russ.)].

Прунч Э. Пути развития западного переводоведения. От языковой асимметрии к политической. М.: Р.Валент, 2015 [Prunč, Erich (2015). Puti razvitija zapadnogo perevodovedenija. Ot jazykovoi asimmetrii k politicheskoi (Ways of Development of Western Translation Studies. From Language Asymmetry to Political One). Moscow, R.Valent (In Russ.)].

Сдобников В.В., Петрова О.В. Теория перевода: учебник для студентов лингвистических вузов и факультетов иностранных языков. М.: АСТ: Восток-Запад, 2006 [Sdobnikov, Vadim, Petrova, Olga (2006). Teorija perevoda (Translation Theory). Moscow, AST; VostokZapad (In Russ.)].

Сдобников В.В. Перевод и коммуникативная ситуация: монография. М.: Флинта: Наука, 2015 [Sdobnikov, Vadim (2015). Perevod i kommunikativnaja situatsija (Translation and Communicative Situation: monograph). Moscow, Flinta: Nauka (In Russ.)]. 
Федоров А.В. Основы общей теории перевода. 4-е изд. М.: Высшая школа, 1983 [Fedorov, Andrei (1983). Osnovy obshchei teorii perevoda (Fundamentals of General Translation Theory). $4^{\text {th }}$ ed. Moscow, Vysshaya shkola (In Russ.)].

Чернов Г.В. Основы синхронного перевода. М.: Высшая школа, 1987 [Chernov, G. (1987). Osnovy sinkhronnogo perevoda (Fundamentals of Simultaneous Interpreting). Moscow, Vysshaja Shkola (In Russ.)].

Швейцер А.Д. Теория перевода: статус, проблемы, аспекты. М.: Наука, 1988 [Svejtser, Aleksandr (1988). Teorija perevoda: status, problem, aspekty (Translation Theory: Status, Problems, Aspects). Moscow, Nauka (In Russ.)].

Ширяев А.Ф. Синхронный перевод: Деятельность синхронного переводчика и методика преподавания синхронного перевода. М.: Воениздат, 1979 [Shiryaev, A.F. (1979). Sinkhronny perevod. Dejatelnost sinkhronnogo perevodchika i metodika prepodavanija sinkhronnogo perevoda (Simultaneous Interpreting: Simultaneous Interpreter's Activity and Methods of Teaching Simultaneous Interpreting). Moscow, Voenizdat (In Russ.)].

Якобсон Р.О. Лингвистика и поэтика // Структурализм: «за» и «против»: Сборник научных статей. М.: Прогресс, 1975. С. 193-230. [Jacobson, R.O. (1975). Lingvistika i poetika (Linguistics and Poetics). Strukturalizm: za i protiv. Moscow, Progress Publishing House. P. 193-230. (In Russ.).].

\section{Bionote:}

VADIM SDOBNIKOV is Professor at Linguistic University of Nizhny Novgorod, Head of Department of the English Language and Translation Theory and Practice, Chairperson of the Board of the Union of Translators of Russia. His research interests embrace translation studies, didactics of translation, intercultural communication. Key publications: Perevod i kommunkativnaja situatsija [Translation and Communicative Situation], Moscow, 2015; Otsenka kachestva perevods: kommunikativno-funktsionalny podkhod [Translation Quality Assessment: Communicative-Functional Approach], Moscow, 2015; In Defense of Communicative-Functional Approach to Translation. Procedia - Social and Behavioral Sciences. 231 (2016), 92-98; Communicative-Functional Approach in Russian Translation Studies: Where Does It Come From? Science Journal of VolSU. Linguistics. 2017. Vol. 16. No. 3, 7179; Translation vs Localization: What's the Difference? Humanities \& Social Sciences: Journal of Siberian Federal University, 2018, 11(9), 1487-1498.

Contact information: e-mail: artist232@rambler.ru

\section{Сведения об авторе:}

СДОБНИКОВ ВАДИМ ВИТАЛЬЕВИЧ - доктор филологических наук, заведующий кафедрой теории и практики английского языка и перевода Нижегородского государственного лингвистического университета им. Н.А. Добролюбова, председатель Правления Союза переводчиков России. Сфера научных интересов: переводоведение, дидактика перевода, межкультурная коммуникация. Основные публикации: Перевод и коммуникативная ситуация: монография. М.: Флинта: Наука, 2015; Оченка качества перевода: коммуникативно-функииональный подход: монография. М.: Флинта: Наука, 2015; In Defense of Communicative-Functional Approach to Translation. Procedia - Social and Behavioral Sciences. 231 (2016), 92 -98; CommunicativeFunctional Approach in Russian Translation Studies: Where Does It Come From? Science Journal of VolSU. Linguistics. 2017. Vol. 16. No. 3, 71-79; Translation vs Localization: What's the Difference? Humanities \& Social Sciences: Journal of Siberian Federal University, 2018, 11 (9), 1487-1498.

Контактная информация: e-mail: artist232@rambler.ru 